\title{
Scientific Approach-Based Textbooks Evaluation: A Content Analysis of English Textbooks on Reflective Teaching in Indonesia
}

\author{
Umi Rachmawati ${ }^{1 *}$ \\ ${ }^{1}$ Faculty of Economics, Universitas Muhammadiyah Magelang, Magelang, Indonesia \\ *Corresponding author. Email: u.rachmawati@ummgl.ac.id
}

\begin{abstract}
The implementation of scientific approach to English as a foreign language teaching faces challenge. The use of Textbooks prepared by the education ministry is expected to be able to provide the effectiveness and flexibility of the teaching to achieve the learning goals. The principles of reflective teaching cannot be separated from the process of English language teaching. This study is aimed at evaluating the Textbooks freely provided by the ministry of education, so-called BSE. A content analysis study was done to see the implementation of scientific approach, student-centred approach, and reflective teaching in textbooks. The principles of scientific approach, student-centred approach, and reflective teaching in foreign language teaching and learning are considered on the textbooks. The textbooks evaluated were English Textbooks for grades 7,8 , and 9 . The findings present the surface level of each of the approach. The scientific approach has not been employed in the textbooks. The principles of student-centred learning are also still on the learnercentred teaching not on the knowledge-centred, assessment-centred, and community-centred. Finally, the reflective approach is underlain both in the middle and the end of the textbooks. The reflection moves on the students' evaluation of their learning materials achievement and less on their character-building aspect. The results of the study are expected to be the evaluation of the textbooks for the betterment of the books and so with the English teaching and learning process.
\end{abstract}

Keywords: English textbooks, content analysis, evaluation, reflective teaching

\section{INTRODUCTION}

English language teaching in Indonesia has been changing in formal classes. It is reflected in the role of English in the curriculum implemented in Indonesia. Previously, English is compulsory for the primary students and so with the upper levels, junior and senior high schools. At least four hours per week, English is taught at the formal schools. The focus of the teaching is to enable the students to communicate with the target language. In line with the development of technology and information and also the current issues of education, the role of English language teaching in Indonesia becomes an extracurricular course for the students of primary schools. The number of hours per week is also decreased into two hours per week for both junior and senior high schools (Kurikulum 2013 New Version). It means that the teaching of English becomes the second line of the "crucial" subjects instead of the primary subjects. Apart from the development of the Indonesian curriculum and its dissemination on the English language teaching, the quality of language teaching is in line with the clear objectives of the curriculum. English is taught to meet the need for international communication. It is also to provide broader opportunities for technological improvements and career developments [1]. The roles of English influence curriculum development through its evaluation process.
Several problems from the evaluation of the implemented curriculum may be identified in a number of aspects. They are allocation of inadequate time for English lessons, lack of resources and learning materials, and low motivation by the students and the stakeholders [2]. As mentioned earlier, the English courses organized in Curriculum 2013 new Rev is shorter than the previous curriculum that brings another problem for the teachers. The teachers should be ready with their efficient and effective instruction to deal with the enormous learning materials in a short period. An additional problem for English instruction is the existence of learning sources. Then, the uncontrolled and stressful instruction that decrease both the students' and stakeholders' motivation to conduct more engaging learning activities. Even though it is compulsory at the senior high school level, the fact that English is not used to teach science subjects reduces the rate through which learners can build up their vocabulary in science and technology-related subjects [2].

The evaluation of the English language teaching does not only include the curriculum but also the textbooks used by both the teacher and the students. Textbooks play important roles in a language program [3]. They convey meaning and knowledge for the learners [4]. They can contain the major source of learning in terms of their learning goals, learning activities and learning goals. They are well depicted in the structure and syllabus.

Evaluating textbooks is done through several principles of language textbooks. There are five principles of textbooks [5]. First of all, textbooks should have structure and a 
syllabus that will be disseminated in a program. The second, textbooks should help standardize the instruction implemented in the course. Third of all, they are developed to expose qualified learning materials. The fourth, they share a variety of learning resources. Finally, the textbooks should be efficient that enable the teacher to dedicate their time to teaching instead of producing learning material.

As mentioned earlier, the role of textbooks bears the structure of the teaching which is influenced by the approach of language teaching. The use of communicative language teaching approach requires the teacher to provide more activities to accommodate the students to have direct communication in the target language. Therefore to evaluate the textbooks, several criteria of textbook evaluation are delivered by Cunningsworth [6]. A good textbook should respond to the learners' needs and facilitate learners with the learning processes. It also should reflect the uses that the learners will make their language production. Lastly, a good textbook should be able to support learning.

From the identification of the problems presented above, there is a need to analyze the textbooks used as the main sources of learning proposed by the Indonesian government through electronic textbooks (BSE). The consideration of the English textbooks for junior high schools is believed crucial due to the position of English in formal education. It is also crucial for analyzing the content of the textbooks in terms of the approaches underlying the textbooks; scientific approach and reflective approach.

\section{SCIENTIFIC APPROACH}

Firstly, the notion of scientific approach was established by the scientific curriculum implemented in the scientific study. Biological scientific curriculum study (BSCD) is to enable the students to process information through biological approach namely, identifying problems and using a particular method to solve them [7]. The process of scientific curriculum study is done through information process, problem identification, and problem-solving. To be able to conduct the whole steps of the scientific approach, the term science should be seen as the core of the learning. Science should provide human needs that are conducted through problem-solving and inquiry-based activities [8]. Science is defined as complete, fixed, and truths that are well structured as new data related to the old ones [7]. The data collected are required to be complete and support the decision making of the problems during the inquiry learning. The inquiry process is affected by the good spirit and comfortable conditions of the learning [9]. The good spirit and comfortable conditions of the learning are absolutely influenced by the learning facilities that provide sufficient instructional media used in the laboratory through scientific approach. The nature of language is not in a vacuum which can be understood as only takes place in laboratory. The use of language is contextual in which the learners should not border the use of the language in a set room. The main functions of language are communication, information, and impact [10]. It should be interdependent, interpenetrated as well as interconnected but it becomes more function of information when the scientific style is disseminated. To be effective in laboratory language learning, the teaching materials developed to integrate the class and laboratory with the focus of speaking and listening language skills [11]. The concept of language teaching is, now, clear that avoid the use of laboratory since the teaching of language skills should be integrated; listening, speaking, reading, and writing. As mentioned by Celce Murcia, in audiolingualism, listening, speaking and reading are requested but writing is postponed [12].

From the extract taken from a number of experts, it is clear that the use of scientific approach can increase the students' inquiry learning skills through the problems solving learning process. In fact, the requirement of using language laboratory limits the process of teaching since it only focuses on listening and speaking skills. It also borders the stand of the language as communication, information, and impact that are interdependent, interconnected, and interpenetrated.

\section{REFLECTIVE TEACHING}

The word reflective is derived from the term reflect which means to think carefully on possibility and opportunities. In relation to the reflection in teaching deals with the process of thinking carefully on the instruction to get the possibility and opportunities of the instruction. For this, reflection can be defined in several ways [13]. (1) Reflection is a way of being a teacher, (2) It is intellectual and effective actions to explore their experiences to develop new understanding and appreciation, and (3) Reflection is an important element of professional growth of teachers. The process of reflection provides experiences for the learners and teachers to teach themselves as it is a way of being a teacher. Lastly, through reflection, it is crucial for the teachers to be more professionals in guiding and facilitating the students to develop themselves.

To achieve the main purposes of reflection, effective choices should be done in the instruction. The choices include a reflective and lifelong learning in which individual engages in an endless process of questioning and making transformation on the learners' capabilities and motivations in response to and in relation to the social changes and expectations of the learning [14]. The changes should be done in accordance with the social changes to be able to get involved in society to have the success of their learning. Reflection is an endless process by which the students think of what they have done and make their betterment of themselves and transform themselves during their lifelong learning. It is not only merely defined as a long process of learning. It generally deals with self-monitoring and evaluation, a repertoire of learning skills, making connections across heterogeneous learning environments and fields that can be done both in formal and informal settings [15], [16]. The thinking about oneself is done to monitor and evaluate what they have done. Being a successful individual requires skills that should be connected in different contexts.

The context of teaching requires teachers to guide and help the students to be able to self-analyze and understand their limits, which can be altered by providing appropriate guidance and resources for the students to take into action 
during their learning [17]. Teachers need to know the essence of knowing and knowledge both in their discipline and pedagogy. They are required to understand different learning styles through different learners' characters to help the students know themselves and how to learn to be selfanalytical and independent. For example by providing fundamental questions in their teaching [13].

Therefore, to deal with those fundamental reflective questions, reflection is cyclical, flexible, focused, and holistic [13]. Cyclical is seen as an endless process of reflective learning in which the learners can have similar learning steps during their self-monitoring and evaluation process. They will move to different steps after they have achieved the indicators of their success. Flexible means the possibility of changing depending on the context they faced. Thus, each student may have different processes and learning indicators. Based on the indicators of their learning, the students are required to be focused to come up with their learning goals. However, their learning cycles should also be holistic that enable the students to be ready with every situation in their society.

\section{METHOD}

This study was conducted in a qualitative way that involves several characteristics. It deals with natural settings, researchers as key instruments, multiple sources of data, inductive data analysis, participants, meanings, emergent design, theoretical lens, interpretive, and holistic account [18]. The main process of the study was done through content analysis. The major process of the study was a content analysis in which it makes inferences by systematically and objectively identifying characteristics of messages [19]. The aspects counted in the study involve items, concepts, and semantic. Items represent the unit of the content. The concept is to build more conceptual clusters while the sematic is how the words affected the readers. The data collection was done from the book as the main document while the researcher was the main data analyst. A number of the process during the content analysis were conducted. They include interpreting the themes, reading the data, organizing and preparing data analysis, coding the data, writing findings. The reliability of the findings is through rich, thick description to convey findings [18]. There were three main books as the main sources of the data; "Buku Bahasa Inggris, When English Rings a Bell Grade 7", "Buku Bahasa Inggris, When English Rings a Bell Grade 8", and "Buku Bahasa Inggris, Think Globally Act Locally Grade 9". This study was actually done to reveal the implementation of scientific approach, studentcentered approach, and reflective approach in the selected electronic English books published by the Ministry of Education and Culture in Indonesia for grades 7, 8, and 9.

\section{RESULTS AND DISCUSSION}

The findings of the study are classified into three major parts as mentioned in the research objectives. The principles of scientific approach, student-centered approach, and reflective approach. Each of those aspects is highlighted below.

\subsection{The Implementation of the Scientific Approach in the Textbooks}

The core concept of the scientific approach during teaching is the highlight of critical thinking skills and problemsolving as conducted in a well-set room or laboratory. From the data taken from Buku Bahasa Inggris, When English Rings a Bell Grade 7, the sub-heading Observation and Asking Questions is given to raise the students' ability in developing their skills of inquiry. In fact, learning materials are only sort of expressions and dialogues that will be used in the unit. Then, the subheadings used in each unit do not represent the scientific approach. The subheadings are (1) Observing and Asking Question, (2) Collecting Information, and (3) Communicating. During the Collecting Information, the students are required to respond to the context of the dialog given by the writer. It does not represent the process of collecting information activities since the students have got the expressions presented in the previous subheadings. The process of communication also does not occur in the laboratory that the students may not have the real experience of learning through scientific approach. In summary, the concept of scientific approach is not highlighted from the beginning of the book until the end of the book. It means that the book has not represented the approach should be undergone by the Curriculum 2013.

The second book of the study is Buku Bahasa Inggris, When English Rings a Bell Grade 8. The book has similar features to the Buku Bahasa Inggris, When English Rings a Bell for Grade 8. The subheadings include (1) Observing and Asking Questions, (2) Collecting Information, and (3) Communicating. The first subheading deals with the same content of the previous book in which the students are requested to read the expressions and practice the dialogues. There is no clear project that should be accomplished during the learning of the unit as has been required by the scientific approach. The same activities are also done during the Collecting Information as has been done in the previous book. However, the difference lies in the Communicating subheading in which the learners are required to write their own journal.

The last book, "Buku Bahasa Inggris, Think Globally Act Locally Grade 9" has different contents. The subheadings of the books include (1) Observing and Questioning, (2) Collecting Information, (3) Reflecting, (4) Associating, and (5) Communicating. The questions written in the textbook are also not for the implementation of critical thinking skills.

"I will ask you what the students and the teacher say to congratulate Lina and to express their hopes for Lina's success. You will answer my questions orally, too.

Listen carefully. First, repeat the examples after me." The instruction above is stated at the end of the first subheading. It clearly does not train the students' higherorder thinking skills and their problem-solving skills too. The Reflection subheading deals with a review of what the students have learned. In fact, the concept of reflection is in terms of the learning process and products. The final 
subheading, Communicating provides opportunities for the students to share their experiences on their learning. However, it does not highlight the concept of scientific approach in which the students should be able to get the sense of their learning.

The instructions in the books analysed have not employed the principles of the scientific approach in language teaching. First, there is no big problem stated for the students to solve. The beginning of the unit only giving information on what the students will have and directly provide exposures on the topic they will learn. Second, the focus of teaching is still on the lower order thinking skills. Third, the implementation of problem-solving skills in teaching has not been done completely. The students are not well guided by the teachers to find information, justify the problems, and making problem-solving. Finally, the use of laboratory during the instruction is also still blurred in which there is no clear instruction for the students and the teacher to use any kind of laboratory during their learning.

\subsection{The Implementation of Student-Centered Approach in The Books}

The student-centered approach requires the knowledgecentered, learner-centered, assessment-centered, and community-centered [20]. The first aspect, knowledgecentered learning, seems to be disseminated in the unit since the students are offered by the use of exposures in each unit. From the first subheading until the final subheading, the students may access any information on the topic discussed which means that the knowledge-centered is altered. However, the reinforcement of the knowledge-center has not come to the max. The focus of the knowledge-center is to train the students' skills in getting information to make their own construction of the learning.

Another aspect of student-center teaching is the implementation of learner-centered. The focus of the learning is on the students. From the activities and the instructions given in each unit, most of the books focus on the learners. The students are expected to be active during learning.

The last aspect of student-centered learning is the implementation of assessment-centered learning. From the data gathered, the three books analyzed have not maximally implemented the principles of assessment-centered learning. As mentioned earlier, the main focus of the book is on the mastery of speaking skills. In fact, there is no clear speaking assessment rubric for the students to know whether they have come to the best level of speaking. The students also do not exactly know the aspects of good speaking performance. If the books share the criteria of the assessment, the students will have their best preparation which might be done during their learning to improve their achievement in the assessments. Then, the activities of the units are still problematic for the students since they have to do the tasks with less explanation on the process. For example, when they have to think of what they need to do to accomplish something, there is no clear guidance for the students to consider and conduct. With the abstract questions found in each task, the students cannot complete the task well.
Eventually, the implementation of the student-centered learning has been done in the units of the books. However, several aspects of the student-centered learning have not underlain completely to come top level of the students' learning achievement. The consideration of knowledgecentered learning, assessment-centered learning, and community-centered learning is still under the expectation that it should be improved.

\subsection{The Implementation of Reflective Approach in The Books}

The final approach is the reflective one that is used to evaluate whether the books have employed this approach. From the data gathered, the two books entitled "Buku Bahasa Inggris, When English Rings a Bell Grade 7" does not provide any section that deals with the reflective teaching. One section for the students' evaluation is only about the students' learning achievement on the materials they have learned. The section is placed at the end of the book and it consists of questions about the topic discussed. There is no question about the students' learning, their learning difficulties, and how to deal with their learning difficulties.

However, in the second and third books, "Buku Bahasa Inggris, When English Rings a Bell Grade 8" and "Buku Bahasa Inggris, Think Globally Act Locally for Grade 9", the writer classified the book into several subheadings. Two of them employ the use of reflective teaching. The first subheading, Reflecting, is stated in the third subheading out of five subheadings. In this subheading, the students are asked to think of what they need to learn. Thus, the subheading offers the learning materials that the students will have during their learning. The statement "I will lead you to reflect on what you are learning now." in Figure 1 is not suitable for the reflection since the reflection should be done at the end of the learning cycle. The students might have their confusion on this since they have not felt the impact of their learning. Then, the following expressions merely explain the use of learning materials. The use of reflective questions as mentioned by Ghaye \& Ghaye should deal with the teaching process and their feeling on their learning [13].

The second subheading about reflective teaching lies in the last subheading entitled Communicating. In Communicating subheading, the students are given several questions about the unit they have learned. However, the questions have not completely represented the principles of reflective teaching. The students should make a journal from their learning by answering several questions, "I have just learnt to ..."." "The activities I like most were ....", "The activities I found most difficult were ....", and "What I need to do better is/are ..." Actually, this part deals with the students' process of reflection but it is on the surface level of the students' reflection. There should be more questions to guide the students with their reflection process which leads to the students' transformation.

The conflict may be raised on the books deals with the labeling of the units. Each unit should represent the core of the labels. It will decrease the students' and the teachers' understanding and first conception of the unit they will pass. 
[7] E. Suryawati, K. Osman, and T. S. Mohd, "The effectiveness of RANGKA contextual teaching and learning on students ' problem solving skills and scientific attitude," Soc. Behav. Sci., vol. 9, pp. 1717$1721,2010$.

[8] S. Zemelman, H. Daniel, and A. Hyde, Best Practice: New Standards for teaching and learning in America's School. 2nd ed. New Hampshire: Heinemann, 1998.

[9] L. S. Jakipova and A. K. Zhunisbayeva, "Teaching the bilingual students: a scientifi approach to foreign language learning," Инновационная наука, vol. 6, no. 2, pp. 136-138, 2015.

[10] C. Joseph, "Audiolingualism: How Effective Is It?," Sch. Life Supreintendent Doc., no. 1, pp. 1-24, 1964.

[11] M. Celce-murcia, Teaching English as a second or foreign language ( $2 \mathrm{nd}$ ed.). Boston Massachusetts: Heinle \& Heinle Publishers, 1991.

[12] A. Ghaye and K. Ghaye, Teaching and learning through critical reflective practice. Scotland: David fulton Publishers Ltd., 2003.

[13] M. Archer, Making our way though the world: Human reflexivity and social mobility. Cambridge: Cambridge University Press, 2007.

[14] R. James and D. Beckett, "Australia: Higher education and lifelong learning: An Australian perspective," in Higher education and lifelong learners: International perspectives on change, $\mathrm{H}$. Schuetze and M. Slowey, Eds. London: Taylor \& Francis, 2013, pp. 171-194.

[15] H. Schuetze and M. Slowey, "Traditions and new directions in higher education: A comparative perspective on non-traditional students and lifelong learners.," in Higher education and lifelong learners: International perspectives on change, $\mathrm{H}$. Schuetze and M. Slowey, Eds. London: Taylor \& Francis, 2013, pp. $1-24$.

[16] Mary Elizabeth Ryan, Teaching reflective learning in higher education: a systematic appraoch using patterns. Switzherland: Springer International Publishing, 2015.

[17] R. B. Barr and J. Tagg, "From Teaching to Learning -- A New Paradigm for Undergraduate Education," Change, vol. 27, no. 6, pp. 12-25, 1995.

[5] Cunningsworth, "No Title," 1995.

[6] B. Joyce, M. Weil, and E. Calhoun, Models of Teaching seventh edition. New York: Pearson Education Inc., 2004. 
centered Learning What is meant by Student-centered

[18] J. C. Richards and T. S. Rodgers, Approaches and Methods in Language Teaching. Cambridge:

Cambridge University Press, 2001.

[19] L. Christensen, Reading, Writing, and Rising Up: Teaching about social justice and the power of the written word. Milwaukee: Rethinking Schools, Ltd., 2000 .

[20] J. Froyd and N. Simpson, "Student-Centered Learning Addressing Faculty Questions about Student-
Learning ( SCL )?," no. 1997, 2000.

[21] J. W. Cresswell, "Research Design: Qualitaive, Quantitaive, and Mixed Method Approaches." Sage Publications Inc., London, 2009.

[22] B. L. Berg, Qualitative Research Methods for the Social Sciences Fourth Edition. Lon: Pearson Education Inc., 2001. 